\title{
Human-Water Dynamics and their Role for Seasonal Water Scarcity - a Case Study
}

\author{
Andreas Nicolaidis Lindqvist ${ }^{1,2}$ (D) $\cdot$ Rickard Fornell $^{1} \cdot$ Thomas Prade $^{2}$. \\ Linda Tufvesson ${ }^{2} \cdot$ Sammar Khalil $^{2}$ - Birgit Kopainsky ${ }^{3}$
}

Received: 5 October 2020 / Accepted: 21 March 2021/ Published online: 17 July 2021

(C) The Author(s) 2021

\begin{abstract}
Ensuring sustainable management and an adequate supply of freshwater resources is a growing challenge around the world. Even in historically water abundant regions climate change together with population growth and economic development are processes that are expected to contribute to an increase in permanent and seasonal water scarcity in the coming decades. Previous studies have shown how policies to address water scarcity often fail to deliver lasting improvements because they do not account for how these processes influence, and are influenced by, human-water interactions shaping water supply and demand. Despite significant progress in recent years, place-specific understanding of the mechanisms behind human-water feedbacks remain limited, particularly in historically water abundant regions. To this end, we here present a Swedish case study where we, by use of a qualitative system dynamics approach, explore how human-water interactions have contributed to seasonal water scarcity at the local-to-regional scale. Our results suggest that the current approach to address water scarcity by inter-basin water transports contributes to increasing demand by creating a gap between the perceived and actual state of water resources among consumers. This has resulted in escalating water use and put the region in a state of systemic lock-in where demand-regulating policies are mitigated by increases in water use enabled by water transports. We discuss a combination of information and economic policy instruments to combat water scarcity, and we propose the use of quantitative simulation methods to further assess these strategies in future studies.
\end{abstract}

Keywords Water $\cdot$ Resource management $\cdot$ Socio-hydrology $\cdot$ Systems thinking $\cdot$ System dynamics

Andreas Nicolaidis Lindqvist andreas.nicolaidis@ri.se

Extended author information available on the last page of the article 


\section{Introduction}

Water scarcity is a growing problem impacting human health, economic development and ecological systems in many regions around the world (Wimmer et al. 2015). Pressure on global freshwater resources, driven by population growth, expansion and intensification of agriculture, urbanization, industrial development and climate change, are expected to push up to $50 \%$ of the world's population into a state of permanent or periodic water insecurity by 2050 (United Nations 2018).

Addressing this challenge requires integrated approaches that account for how water acts as a link between different parts of society and nature. Better understanding of how actions in one part of the interconnected social, hydrological and ecological system, may have cascading effects across space and time is pressingly needed (United Nations 2018). Integrated Water Resources Management (IWRM) (Gorre-Dale 1992) is the dominating approach used in the management and planning of water resources. However, the IWRM approach has gained critique for treating the social and hydrological sectors as isolated subsystems that to a large extent develop independently from one another (Blair and Buytaert 2016). This approximation may be sufficient for short-term management but for long-term planning and policy making, failing to account for the bidirectional human-water feedbacks can lead to unintended consequences and "policy resistance" (Di Baldassarre et al. 2019; Sterman 2000a).

Policy resistance is the phenomenon where well-intended policy solutions fail to produce their desired outcomes due to unanticipated feedback effects, triggered endogenously by the causal structure of the targeted system (Sterman 2000a). Two well-documented examples of policy resistance with respect to socio-hydrological interactions are "Water Rebound Effects" (Beal et al. 2014), where improvements in efficiency lead to higher total consumption, in addition to "Supply-Demand Cycles" (Kallis 2010), where increases in water supply capacity enable growth that generate further capacity demand. These phenomena occur because policies are designed and implemented without taking into account the two-way feedbacks between the physical, technical and social dimensions of the human-water system, leading to counterintuitive changes in water demand (Di Baldassarre et al. 2019).

Over the last years, considerable progress has been made in building macro-level theories on how socio-hydrological interactions influence water system behavior, and in the scientific community there is a strong consensus on the importance of accounting for these interactions in water management and planning (Di Baldassarre et al. 2019; Langarudi et al. 2019). Despite these advancements, in-depth and place-specific understanding of the mechanisms behind human-water feedbacks remain limited ( $\mathrm{Xu}$ et al. 2018). Among practitioners the water management and planning process still relies heavily on hydrological and socio-economic forecasts largely conducted in isolation from one another (Di Baldassarre et al. 2019). To address this knowledge gap, further case-based studies are needed that can generate insights on the role of human-water feedbacks in different social and hydrological settings (Blair and Buytaert 2016).

Among published socio-hydrological case studies, regions with a long history of water scarcity (including the Mediterranean, the Middle East, Australia, parts of the US and parts of Africa) are relatively well-represented (Blair and Buytaert 2016). In contrast, Sweden and other historically water-abundant regions are poorly represented. However, unusually dry weather conditions in recent years have caused local-to-regional seasonal water scarcity to become a growing problem even in these typically water-abundant areas (Ahopelto et al. 2019). With the effects of climate change, this development is likely to continue in the coming 
decades (Asp et al. 2015). Thus, understanding how socio-hydrological interactions influence water scarcity, and how to manage these interactions, is pressingly needed to guarantee a sustainable future water supply also in hitherto water secure regions.

To this end, we here present a case study from the Swedish island Fårö where we investigate in what ways human-water interactions have contributed to policy resistance, leading to reoccurring and increasingly severe, periods of seasonal water scarcity over the last two decades. We apply a systems thinking (ST) approach, using qualitative system dynamics (SD) to identify the key humanwater feedbacks contributing to seasonal water scarcity. The SD method is well-established in the field of social systems modeling in general and socio-hydrological modeling in particular (Bahaddin et al. 2018; Di Baldassarre et al. 2019), and focuses on capturing how the interactions of biophysical and social processes drive overall system behavior. The strength of the method is in its flexibility to model both physical and behavioral processes, and its transparency and ability to shed light on the dynamics emerging from interacting processes in the studied system (Di Baldassarre et al. 2015). We first present the methodology applied to assess the links between the society and the water systems and the logic we use to connect these. Specifically, the identified feedbacks are synthesized into a causal map, providing a conceptual model of the socio-hydrological processes governing water supply and demand on Fårö. As a second step, the conceptual model is used to analyze why historic policies to combat water scarcity have turned out ineffective, and directions for future water management are suggested based on the causal structure of the system. Findings from the study will contribute to building well-needed conceptual understanding of how socio-hydrological dynamics can influence water supply and demand at the local-to-regional scale and push previously water secure areas into water scarcity. This knowledge is important for assisting communities and practitioners in proactive water management and planning. The causal map developed in this paper will be used as a basis for further developing a quantitative simulation model that allows assessing the direct and indirect, short- as well as long-term, effects, synergies and tradeoffs, of different policy measures on the availability of water and socio-economic development, on Fårö and other regions. The quantitative model will be presented in a forthcoming paper by the authors.

\section{Materials and Methods}

\subsection{Study Area}

Fårö island $\left(57.9^{\circ} \mathrm{N}, 19.1^{\circ} \mathrm{E}\right)$ is located in the Baltic Sea and belongs to the Swedish municipality of Gotland. The area is approximately $114 \mathrm{~km}^{2}$ with a yearly precipitation of about 500-600 $\mathrm{mm}$ and average summer and winter temperatures of $16^{\circ} \mathrm{C}$ and $-2{ }^{\circ} \mathrm{C}$, respectively (SMHI, retrieved 202102-03). The island has about 300 permanent households and 725 part-time households, used mainly in the summer period, and tourism and agriculture are the dominating industries. The geology is dominated by limestone bedrock covered by a thin layer $(0-1 \mathrm{~m})$ of postglacial sediments and sedimentary rock. Due to the geological features, most of the groundwater aquifers are small and respond quickly to changes in weather and/or extraction rates. The only exception is a comparatively large aquifer located in the northeastern part of the island where deep layers of aeolian sand sediments (up to $20 \mathrm{~m}$ in depth) allows for considerable groundwater extraction and storage (SGU geokartan, 2021-02-03). This is where the only municipal water plant on the island is located and from here a public grid supplies water to the majority of the tourist facilities, and about 50 residential households. Households outside the public grid rely on private wells for their water supply (Region Gotland 2014; Sjöstrand et al. 2014). 
Over the last two decades, Fårö has developed into a popular tourist destination. During peak season (June - August) about 10,000 tourists and part-time residents visit the island (Region Gotland 2014). The visitors are concentrated in the area around the public grid where most of the tourist attractions are located, creating a sharp increase in water consumption that coincides with the seasonal low point in groundwater generation, putting a lot of pressure on the municipal water system.

The municipal water plant started experiencing problems keeping up with demand in the early 2000's. Since 2006, water demand has exceeded supply capacity every summer and the municipality has been supplementing the local plant with water transported by truck from neighboring regions of Gotland. Over the years, several policy measures have been introduced by the municipality to reduce the reliance on transported water (Table 1).

Despite the abovementioned efforts, the extent of the transports has grown from about $1500 \mathrm{~m}^{3}$ in 2006 to more than $3000 \mathrm{~m}^{3}$ in 2019 , with a record peak in 2016 when $5500 \mathrm{~m}^{3}$ of water was delivered. The only exception to the trend was 2017 when transports were reduced due to the exploitation of a new aquifer that was later terminated (Table 1). To meet peak season demand (approximately eight weeks every summer) the municipal water services are at present relying on daily water deliveries (Region Gotland personal communication, 2020-05-11). This is not only economically costly for the municipality; low water self-sufficiency is also a significant risk for the region if the water supply-chain would be disrupted. Furthermore, according to recent economic and climate projections for the region, water demand is likely to continue to increase in the coming 30 years, and supply is expected to become increasingly unpredictable. Together, these two trends are likely to further increase the pressure on the water supply systems on Fårö (Eklund 2018).

Table 1 Public policies adopted to reduce reliance on water transports

\begin{tabular}{|c|c|c|}
\hline Policy & $\begin{array}{l}\text { Year of } \\
\text { introduction }\end{array}$ & Description \\
\hline $\begin{array}{l}\text { Restrictions on new } \\
\text { connections to the public } \\
\text { grid }\end{array}$ & 2000 & $\begin{array}{l}\text { A full stop on new connections to the public water grid is enacted. } \\
\text { No new requests are accepted until local water self-sufficiency } \\
\text { can be ensured. Exceptions are made to communities of } \\
\text { households where inadequate drinking water supply or quality } \\
\text { poses a threat to human health. }\end{array}$ \\
\hline Water use restrictions & 2007 & $\begin{array}{l}\text { Consumers connected to the public grid are prohibited to use water } \\
\text { from the municipal grid for gardening and swimming pools. In } \\
2007 \text { the restrictions applied from June to September, but the } \\
\text { duration was gradually extended, and since 2016, restrictions } \\
\text { apply from April to October. }\end{array}$ \\
\hline Information campaigns & 2007 & $\begin{array}{l}\text { Information on the state of groundwater resources starts being } \\
\text { communicated by the municipality on their website. }\end{array}$ \\
\hline $\begin{array}{l}\text { Minimum well-capacity re- } \\
\text { quirements }\end{array}$ & 2008 & $\begin{array}{l}\text { Documentation of a minimum well-capacity of } 6001 \text { per hour } \\
\text { becomes a requirement for building permits to be issued to new } \\
\text { off-grid house construction projects. }\end{array}$ \\
\hline New aquifer exploitation & 2016 & $\begin{array}{l}\text { A new municipal aquifer is identified and taken into use in } 2016 \text { to } \\
\text { supplement the existing aquifer. Exploitation of the aquifer is } \\
\text { terminated in } 2018 \text { due to unsatisfactory water quality. }\end{array}$ \\
\hline Information campaigns & 2017 & $\begin{array}{l}\text { An information campaign to encourage water savings in } \\
\text { households and among tourists is launched. Information and } \\
\text { encouragement to use water more efficiently is communicated } \\
\text { in media, on tourist resorts and on the ferry to the island. }\end{array}$ \\
\hline
\end{tabular}




\subsection{Methods}

The assessment in this paper was conducted in two steps. First, a conceptual model, based on participatory modelling exercises and municipal reports and planning documents, was designed and validated (section 2.2.1.). Then, the model was used to identify and analyze potential feedback mechanisms responsible for the increase in water scarcity on Fårö in the past two decades (section 2.2.2.).

\subsubsection{Model Development}

To model the key human-water interactions on Fårö we adopted an approach grounded in qualitative SD modeling, utilizing and triangulating a variety of different information and data sources including participatory modeling, literature, statistical data and expert knowledge (Martinez-Moyano and Richardson 2013). The entire process was conducted in close collaboration with the Department of Water Management at Region Gotland (RG), together with representatives from Geological Survey of Sweden (SGU) and the Gotland County Administrative Board. A total of 14 participants, including water utility engineers, technicians, water and environment strategists, hydrogeologists and county water administrators participated in the model development process (see supplementary information for details). The participants had no prior experiences in SD modeling but were given an introduction to the concepts of positive and negative causal relationships, causal mapping, and how circular chains of causality can form feedback loops (Table 2), at the start of each modeling activity. Meetings, workshops and modeling sessions were all conducted online using the Microsoft Teams video meeting function.

Model development started by semi-structured group discussions with representatives from RG. The questions had been prepared beforehand and during the meeting the researchers acted as facilitators, presenting the questions, taking notes, and moderating the discussions. First, the participants were asked to describe how public and private water supply, water demand and water sufficiency had been changing on Fårö over the period from 2000 to 2019. Based on the descriptions, the researchers sketched the behavior of the described variables on "behavior over time" (BOT) graphs (Andersen and Richardson 1997). Time was represented on the horizontal axis and the state of the factor of interest, represented by the vertical axis, was sketched as a continuous variable changing over time according to the participant descriptions. From the BOT graphs, general trends in behavior were elicited together with the participants (e.g. accelerating increase, accelerating decline, oscillations, etc.). These trends were described as the overarching behavior modes, the problem reference modes, of the Fårö human-water system (Sterman 2000b). The participants were then asked to describe: (I) what they conceived as the underlying causes, the drivers, to the behaviors presented in the elicited graphs; (II) what effects these changes in water supply, demand and sufficiency had triggered (public policies, consumer behavior changes, etc.); and (III) if there were other socio-economic or biophysical trends they had witnessed during the same time period that could have influenced water supply, demand and/or sufficiency. Results from the session were documented to be used in the forthcoming modeling process before the meeting was closed.

After the group discussions, the behaviors elicited from the participants were validated by comparing them to statistical data from Statistics Sweden (https:/www.scb.se/en/) and RG. The validation of the suggested cause-effect relationships was conducted by structure examination tests (Schwaninger and Groesser 2016); suggested causal connections were crosscompared against findings from previous studies on Fårö (Brunner 2014; Rivera et al. 2011; 
Table 2 Top section: graphical notation and polarity of causal relationships used in model development. Bottom section: examples and behavior of reinforcing and balancing feedbacks. Adapted from Mirchi et al. (2012)

Causal
relationship
A change in the state of $\mathrm{A}$
causes the state of B to
change in the same
direction; all else equal, if
A increases/decreases, B
increases/decreases to a
state above/below what it
would otherwise have
been.
relationships
All else equal, a change
in the state of A causes
the state of B to change in
the opposite direction; all
else equal, if A
increases/decreases, B
decreases/increases to a
state below/above what it
would otherwise have
been.

Behavior
Reedback loop
feedback. If the state of $\mathrm{A}$
changes, this causes a
change in $\mathrm{B}$ that feeds
back to amplify the
change in A.

Balancing (negative) feedback. If the state of A changes, this causes a change in B that feeds back to negate/dampen the change in $\mathrm{A}$.

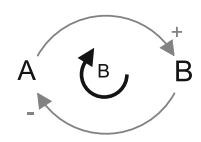

Behavior: balancing change, stabilizing around a reference or goal level.

Notation used in causal maps: a curved arrow with a capital B.

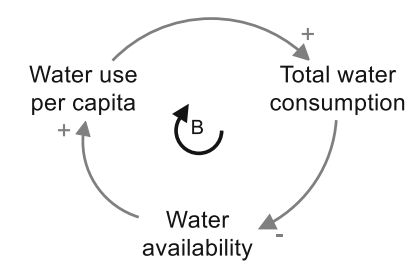


Sjöstrand et al. 2014), and the perspectives of subject experts to assess how well they matched established understanding of the system. For instance, hydrogeologists from SGU were consulted for validation of statements regarding hydrology and groundwater processes. When no data or previous studies were available to confirm a causal statement or trend, it was crosschecked for consistency with the statements from other participants in the study. The suggested trend was assumed to be substantiated if there was uniform agreement about its overall behavior (e.g. increasing, decreasing, oscillating) among the participants. If there was disagreement, the suggested trend was further discussed in subsequent modeling sessions until consensus could be reached.

Following validation, the BOT graphs and elicited drivers were used as a starting point from which the chains of cause and effect were modeled backwards, striving towards providing an endogenous explanation to the elicited trends according to methods described by MartinezMoyano and Richardson (2013) and Sterman (2000b). To achieve a consistent causal explanation, the driving variables provided by the study participants were complemented by additional auxiliary variables from previous studies (Brunner 2014; Eklund 2018; Rivera et al. 2011; Sjöstrand et al. 2014) and follow-up discussions with the participants. From this process the first draft of the causal map was developed by the modeling team.

Structural validation and further refinement of the causal map were conducted through a modeling workshop with the project participants. The draft model was presented on screen and in a step-by-step fashion the researchers guided the participants through the entire model, explaining the logic and assumptions of each causal link. The participants were asked to critically review each link presented and indicate if they agreed or disagreed with the suggested causation and polarity. The participants were also prompted to provide suggestions for changes and improvements to the presented model structure. Suggested changes were discussed within the group until consensus regarding their validity and place in the model structure was reached. Structural adjustments suggested were documented and implemented to the model structure by the research team after the workshop, generating an updated model draft. This cycle of participatory validation and adjustments was repeated twice at which point no further changes to the model structure were voiced. The result was a final conceptual model of the socio-hydrological processes regulating water supply, demand, and sufficiency on Fårö.

\subsubsection{Model Analysis}

Being able to distinguish which feedback loops in a system are responsible for generating an observed behavior can provide qualitative information about suitable direction and design of future policy interventions (Mirchi et al. 2012; Sterman 2000a). To this end, the conceptual model developed in 2.2.1. was analyzed for feedback loops and these were labeled according to the notations described in Table 2. By comparing the reference modes elicited in 2.2.1. with the feedback structure in the model, initial hypotheses about feedback loops that drive system behavior at any point in time in the past could be identified (Bahaddin et al. 2018).

Results from the feedback loop analysis were used to examine why historic policy interventions to mitigate water scarcity had been ineffective. Lastly, the feedback structure was used to provide directions for future water management policies by identifying intervention points in the system that might help to shift loop dominance and loop direction towards more desirable outcomes. 


\section{Results}

Results from the model development and the model analysis process are presented in section 3.1. and section 3.2. respectively.

\subsection{Historic Behavior and Model Structure}

BOT graphs of problem variables and trends elicited in the initial group discussions are presented in Table 3 and the individual model variables in the final model are presented in Table 4 together with their causal relationships. The full conceptual model is presented in Fig. 1.

\subsection{Results from Feedback Loop Analysis}

The final model consisted of a total of 14 feedbacks loops (Fig. 1 and Table 5). Dynamic hypotheses derived from comparing the feedback structure of the model with the reference modes in Table 3 are presented below.

Table 3 Dynamic behavior of key problem variables and trends elicited and validated during the model development process. Modes of validation used include comparison to statistical data provided by Statistics Sweden [A] or RG [B], literature [C] (reference in brackets), expert judgement by hydrogeologists from SGU [D], and agreement within the project group [E]

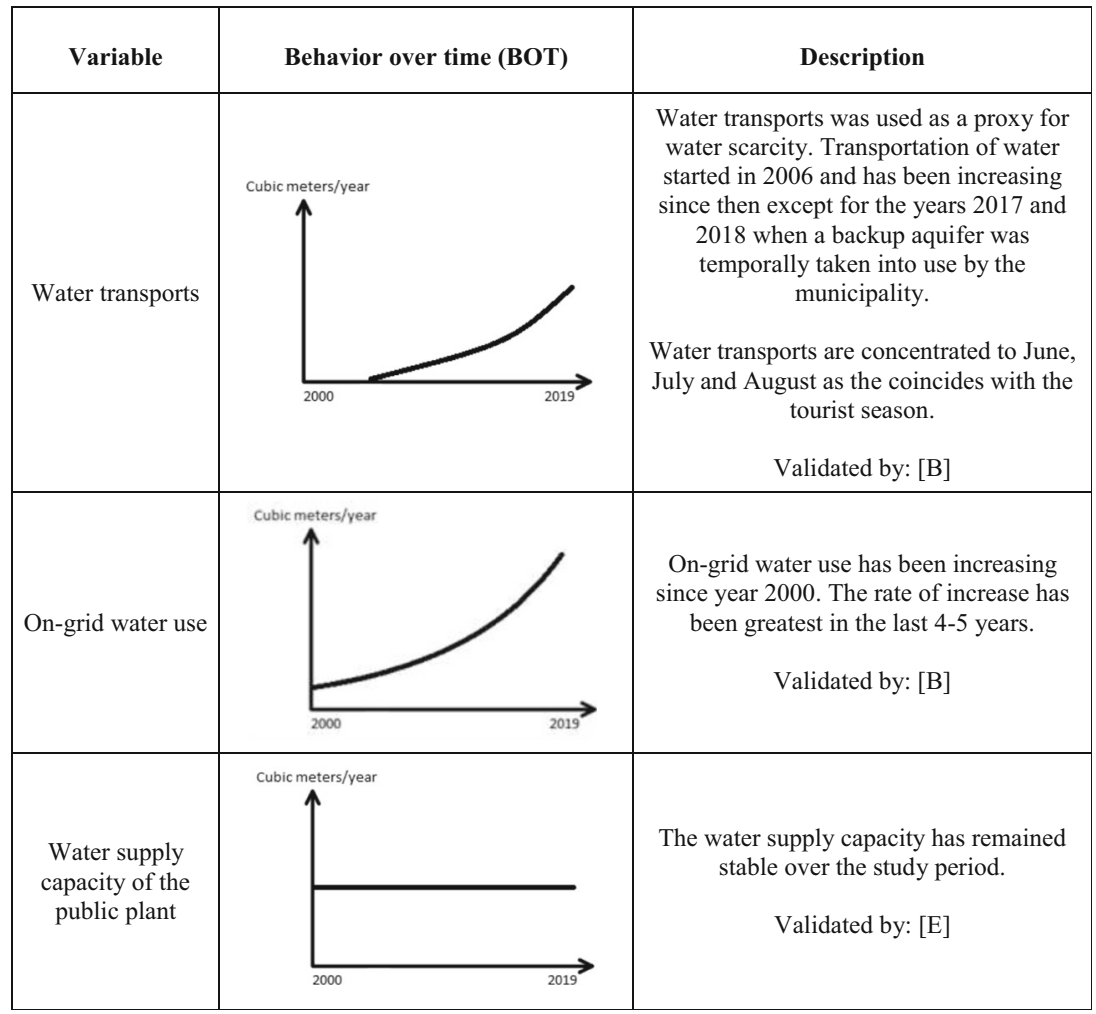




\begin{tabular}{|c|c|c|}
\hline $\begin{array}{c}\text { Off-grid } \\
\text { households }\end{array}$ & off-grid households & $\begin{array}{l}\text { The number of off-grid households have } \\
\text { been steadily increasing for most of the } \\
\text { study period but in the last years the } \\
\text { growth shows tendencies of slowing down } \\
\text { due to difficulties in finding housing sites } \\
\text { with sufficient groundwater supplies. } \\
\text { Validated by: [B, C, E] } \\
\text { (Brunner 2014) }\end{array}$ \\
\hline $\begin{array}{c}\text { On-grid } \\
\text { households }\end{array}$ & on-grid households & $\begin{array}{l}\text { The number of on-grid households } \\
\text { increased up to } 2006 \text { and have since then } \\
\text { remained stable due to restrictions on new } \\
\text { connections to the public grid. } \\
\text { Validated by: [E] }\end{array}$ \\
\hline $\begin{array}{l}\text { Housing } \\
\text { standards }\end{array}$ & Average housing standards & $\begin{array}{l}\text { Average housing standards have been } \\
\text { increasing over the study period. } \\
\text { Validated by: }[\mathrm{E}]\end{array}$ \\
\hline Tourists per year & Tourists pervear & $\begin{array}{c}\text { The number of tourists per year have been } \\
\text { increasing over the study period. The rate } \\
\text { of increase has been accelerating in the } \\
\text { last ten years. } \\
\text { Validated by: [A, C, E] } \\
\text { (Brunner 2014) }\end{array}$ \\
\hline
\end{tabular}

\section{Discussion}

\subsection{What Drives the Increasing Water Transports and why Have Previous Policies Been Ineffective?}

To explain the historic growth in water transports illustrated in Table 3 one needs to understand the combined effects of the feedback loops in the system. Water transports is a response to the on-grid water gap and occurs when total-on-grid water use exceeds the on-grid water supply. This is a supply-targeting policy and through B1 it can quickly close the gap by supplementing the local water system with water from an exogenous source. Loop $B 4-B 6$ and $B 7$ on the other hand reduce the gap by lowering water use by imposing physical constraints, increasing awareness among consumers, and/or by slowing down growth in tourism and housing standards. These balancing processes (increasing supply or reducing consumption) can both individually stabilize water transports, but in combination they can, counterintuitively, cause it to 
Table 4 Variables and causal relationships included in the final model. Variable definition is provided in italic under the variable name in the left most column. Modes of validation follow the same logic as described in Table 3

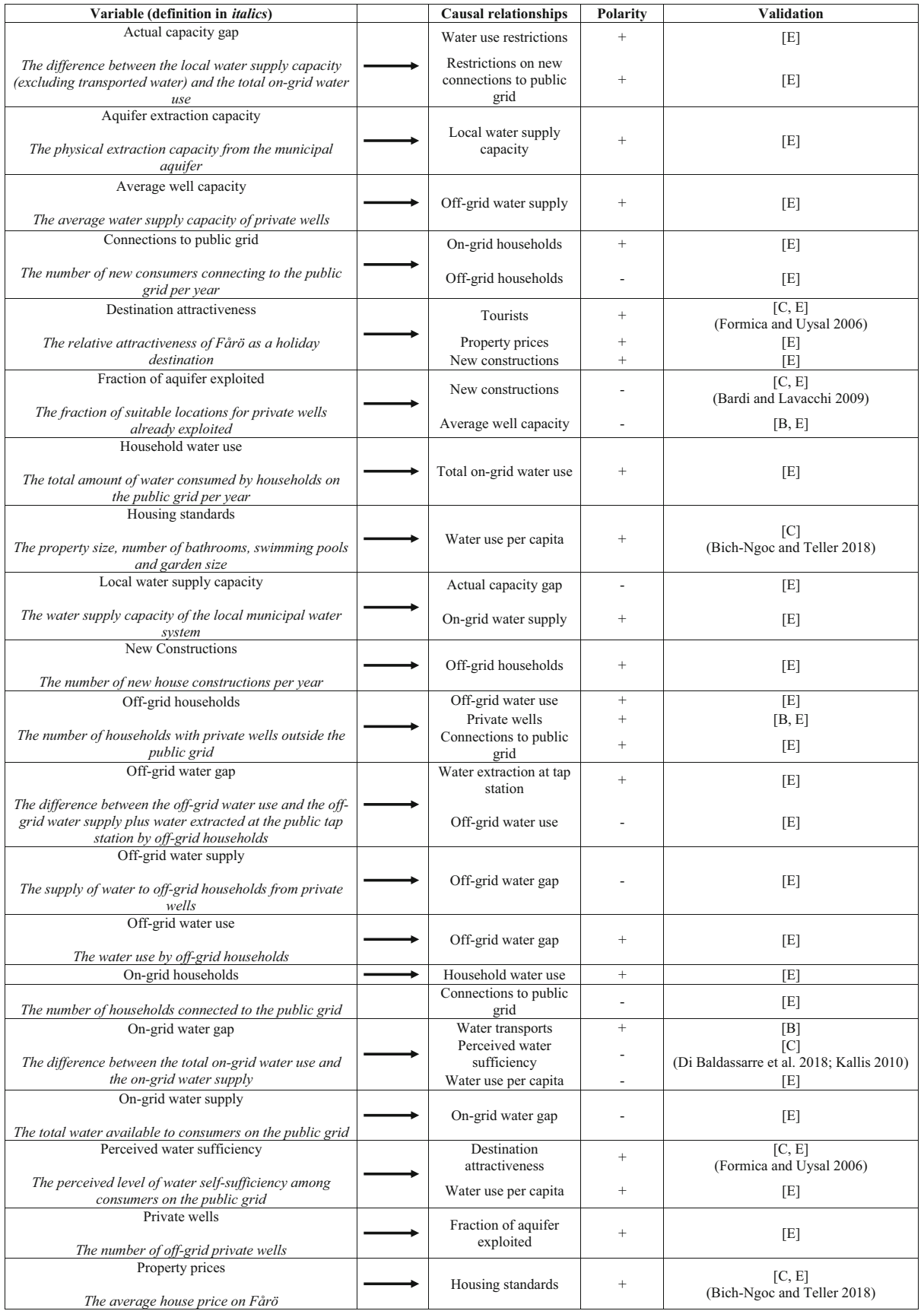




\begin{tabular}{|c|c|c|c|c|}
\hline $\begin{array}{l}\text { Restrictions on new connections to public grid } \\
\text { The extent and duration of restrictions issued by the } \\
\text { municipality, limiting the possibilities for new households } \\
\text { to connect to the public grid }\end{array}$ & & $\begin{array}{l}\text { Connections to public } \\
\text { grid }\end{array}$ & - & {$[\mathrm{E}]$} \\
\hline $\begin{array}{l}\text { Tourists } \\
\text { The number of tourists visiting Fårö every year }\end{array}$ & & $\begin{array}{l}\text { Total on-grid water use } \\
\text { Water extraction at tap } \\
\text { station }\end{array}$ & + & $\begin{array}{l}{[\mathrm{E}]} \\
{[\mathrm{E}]}\end{array}$ \\
\hline $\begin{array}{c}\text { Water extraction at tap station } \\
\text { The amount of water extracted from public tap stations }\end{array}$ & & $\begin{array}{l}\text { Total on-grid water use } \\
\text { Off-grid water gap }\end{array}$ & + & $\begin{array}{l}{[\mathrm{E}]} \\
{[\mathrm{E}]}\end{array}$ \\
\hline $\begin{array}{c}\text { Water plant capacity } \\
\text { Technical extraction capacity of the municipal water } \\
\text { plant }\end{array}$ & & On-grid water supply & + & [E] \\
\hline $\begin{array}{l}\text { Water use per capita } \\
\text { The average water use per person and year }\end{array}$ & & Household water use & + & [E] \\
\hline $\begin{array}{l}\text { Water use restrictions } \\
\text { The extent and duration of water use restrictions applying } \\
\text { to consumers on the public grid }\end{array}$ & & Water use per capita & - & [E] \\
\hline
\end{tabular}

escalate: When B1 closes the on-grid water gap by increasing supply, this contributes to maintaining a perception of water sufficiency among consumers. Incentives to save water erode (B4), and in the longer-term this drives investments in water-demanding capital, e.g. the expansion of tourist capacity and the improvement of housing standards (B5-B7). This combination of balancing feedback loops can help explain why historic policies to reduce consumption (see Table 1) have been ineffective in providing lasting reductions on water use.

Many of the investments in water-demanding capital that are made possible thanks to the water transports are long-lived. For instance, a new hotel may have a lifetime of several decades during which it will require a steady water supply to operate. Therefore, water transports indirectly contribute to slowly increasing the water supply necessary for the island to meet the minimum requirements of its businesses and households. This phenomenon of increased supply causing an increase in demand, also known as supply-demand cycles (Kallis 2010), can help explain the growth in on-grid water use, tourists and water transports presented by the BOT graphs in Table 3 .

The long lifetime of the water-consuming capital can also help explain why historic policies to decrease water use have been ineffective in reducing water transports. New investment decisions are made with the expectation that water transports will continue and water supply will remain high. Once the investments have been made it is very difficult for the municipality to phase out water transports, thereby reducing water availability back to its previous level, without negatively impacting investors (Greve et al. 2018). This results in a systemic lock-in, a phenomenon where historic events determine the future behavior of the system. These effects are well-documented in studies on human-energy systems (Seto et al. 2016), and our results suggest system lock-ins can also arise in human-water systems where they can greatly interfere with future water management policies. These findings are in line with previous studies (Markolf et al. 2018) and illustrate the importance of understanding and assessing the potential the systemic impacts of water management strategies. 


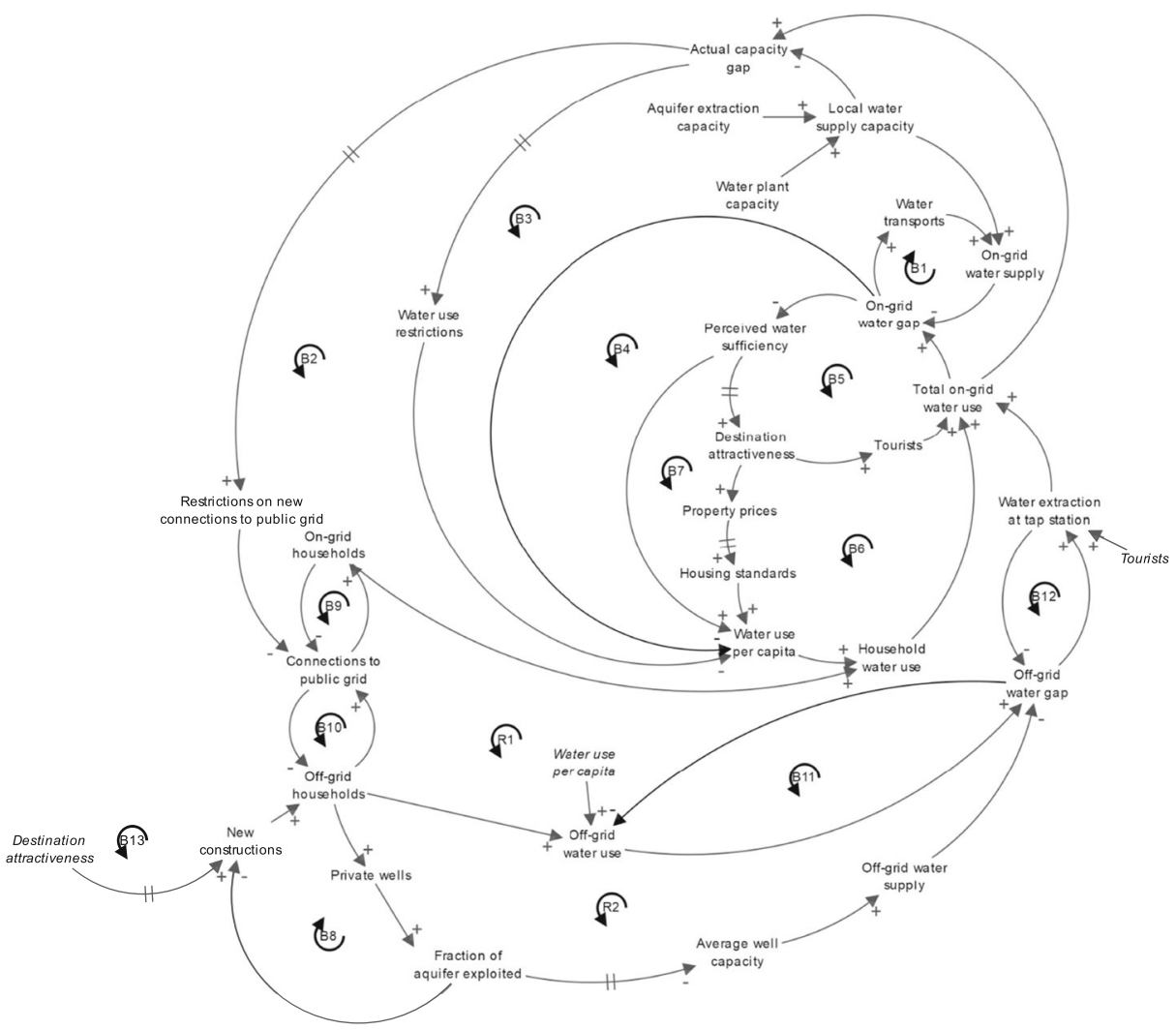

Fig. 1 Final conceptual model derived from the causal relationships described in Table 4. Causal connections with double dashed bars indicate that there is a time delay between cause and effect. Curved arrows with a capital B/R represent balancing and reinforcing feedback loops respectively according to the notation explained in Table 2

As illustrated in Fig. 1, there is a distinction between the on-grid water gap and the actual capacity gap. The on-grid water gap puts a physical limit to consumer water use (if the gap grows too big, supply failures start occurring) but the actual capacity gap is the difference between the local water supply capacity of the public system and the total on-grid water use. In contrast to the on-grid water gap that can be periodically closed by supplementing supply with transported water, the actual capacity gap has been growing throughout the study period as water use has increased but local supply capacity has remained steady (see Table 3 ). The growing actual capacity gap has caused municipal water use restrictions to increase in both scope and duration during the study period (B3) and caused a decline in the number of new connections to the public grid (B2). Even though small reductions in water use have been attributed to these restrictions (about 10-15\% decrease, Region Gotland personal communication 2020-05-11) and the number of on-grid households have stabilized (Table 3), the reductions in total on-grid water use have not been permanent. After a 12-24 month delay following observed effects of restrictions, water use has tended to return to, or above, its previous levels (Region Gotland personal communication, 2020-05-11). This suggest that loop $B 2$ and $B 3$ are insufficient to counteract the growth in water consumption caused by the supply-demand cycles described above. 
Table 5 Identified feedback loops and a description of the dynamic behavior they generate in the context of the study. Loop numbers with the prefix $\mathrm{B} / \mathrm{R}$ represent balancing and reinforcing feedback loops respectively according to the notation explained in Table 2

Feedback Description
loop

B1 Causal chain: on-grid water gap $\rightarrow$ on-grid water supply $\rightarrow$ water transports $\rightarrow$ on-grid water gap

Behavior: as the on-grid water gap expands this trigger more water transports which closes the gap by increasing the on-grid water supply.

Causal chain: total on-grid water use $\rightarrow$ actual capacity gap $\rightarrow$ restrictions on new connections to public grid $\rightarrow$ connections to public grid $\rightarrow$ on-grid households $\rightarrow$ household water use $\rightarrow$ total on-grid water use

Behavior: when total on-grid water use grows, this expands the actual capacity gap, which makes the municipality enforce stronger restrictions on new connections to public grid. The restrictions reduce the number of connections to the public grid, thereby maintaining the number of on-grid households and household water use lower than and they would otherwise have been which reduces total on-grid water use.

Causal chain: actual capacity gap $\rightarrow$ water use restrictions $\rightarrow$ water use per capita $\rightarrow$ household water use $\rightarrow$ total on-grid water use $\rightarrow$ actual capacity gap

Behavior: if household water use increases, total on-grid water use will also increase, and the actual capacity gap expands. The expanded gap causes the municipality to enforce stronger water use restrictions which drives down water use per capita and makes household water use decline again.

Causal chain: on-grid water gap $\rightarrow$ water use per capita $\rightarrow$ household water use $\rightarrow$ total on-grid water use $\rightarrow$ on-grid water gap

Behavior: if the on-grid water gap grows very large this will eventually cause water use per capita to decrease due to supply failures. The reduction in water use per capita will cause household water use and total on-grid water use to decrease, eventually reducing the on-grid water gap.

Causal chain: on-grid water gap $\rightarrow$ perceived water sufficiency $\rightarrow$ destination attractiveness $\rightarrow$ tourists $\rightarrow$ total on-grid water use $\rightarrow$ on-grid water gap

Behavior: if the on-grid water gap increases to a level where it starts influencing water supply to tourist facilities this will cause the perceived water sufficiency to decline, reducing the destination attractiveness of Fårö. Falling destination attractiveness will cause the number of tourists to decline and total on-grid water use to go down, making the on-grid water gap shrink due to lower demand.

Causal chain: on-grid water gap $\rightarrow$ perceived water sufficiency $\rightarrow$ destination attractiveness $\rightarrow$ property prices $\rightarrow$ housing standards $\rightarrow$ water use per capita $\rightarrow$ household water use $\rightarrow$ total on-grid water use $\rightarrow$ on-grid water gap

Behavior: if the on-grid water gap is closed, the perceived water sufficiency goes up and destination attractiveness increases. Higher destination attractiveness leads to higher property prices which over time drives up housing standards. Higher housing standards increases average water use per capita, increasing household water use and total water use, causing the on-grid water gap to expand again.

Causal chain: on-grid water gap $\rightarrow$ perceived water sufficiency $\rightarrow$ water use per capita $\rightarrow$ household water use $\rightarrow$ total on-grid water use $\rightarrow$ on-grid water gap

Behavior: if the perceived water sufficiency increase, this causes an increase in water use per capita, higher household water use and a growing total on-grid water use. The increased water use causes the on-grid water gap to expand and perceived water sufficiency among consumers declines again.

Causal chain: off-grid households $\rightarrow$ private wells $\rightarrow$ fraction of aquifer exploited $\rightarrow$ new constructions $\rightarrow$ off-grid households

Behavior: When the number of off-grid households increase, this leads to more private wells being drilled and the fraction of aquifer exploited increases. This pushes down the number of new constructions because it gets progressively harder to find new housing sites with

sufficient aquifer capacity for exploitation, thereby reducing further growth in off-grid households.

Causal chain: on-grid households $\rightarrow$ connections to public grid $\rightarrow$ on-grid households

Behavior: If the number of on-grid households increase fewer new connections to public grid will be allowed by the municipality, keeping the number of on-grid households below what they would otherwise have been. 
Table 5 (continued)

Feedback Description

loop

B10 Causal chain: off-grid households $\rightarrow$ connections to public grid $\rightarrow$ off-grid households

Behavior: The municipality generally do not approve new households to connect to the public grid because of the current low level of water self-sufficiency. However exceptions are sometimes made and thus, if the number of off-grid households increase the number of new connections to the public grid will also increase, thereby reduce the number of off-grid households below what it would otherwise have been.

B11 Causal chain: off-grid water use $\rightarrow$ off-grid water gap $\rightarrow$ off-grid water use

Behavior: If the off-grid water use increases this will increase the off-grid water gap, and if the gap grows big enough it will reduce the off-grid water use below what it would otherwise have been.

B12 Causal chain: water extraction at tap station $\rightarrow$ off-grid water gap $\rightarrow$ water extraction at tap station

Behavior: If the off-grid water gap increases, e.g. because demand exceeds the supply capacity of the private wells, this will lead to more households having to go to the municipal tap station to get their water. Water extraction at the public tap station will increase and the off-grid water gap to be momentarily reduced.

Causal chain: destination attractiveness $\rightarrow$ new constructions $\rightarrow$ off-grid households $\rightarrow$ off-grid water gap (either via off-grid water use or via private wells) $\rightarrow$ water extraction at tap station $\rightarrow$ total on-grid water use $\rightarrow$ on-grid water gap $\rightarrow$ perceived water sufficiency $\rightarrow$ destination attractiveness

Behavior: If the destination attractiveness of Fårö increases this leads to more new constructions and therefore a growth in the number of off-grid households. More households lead to a greater off-grid water use and a growing off-grid water gap. The off-grid gap is closed by increasing water extraction at tap station, which increases the total on-grid water use. This leads to a greater on-grid water gap (effectively moving the gap from off-grid to on-grid). The growing on-grid water gap contributes to a lower perceived water sufficiency, dampening further growth in destination attractiveness.

Causal chain: actual capacity gap $\rightarrow$ restrictions on new connections to public grid $\rightarrow$ connections to public grid $\rightarrow$ off-grid households $\rightarrow$ off-grid water use $\rightarrow$ off-grid water gap $\rightarrow$ water extraction at tap station $\rightarrow$ total on-grid water use $\rightarrow$ actual capacity gap

Behavior: When the actual capacity gap grows the municipality imposes more restrictions on new connections to the public grid. More restrictions cause fewer connections to the public grid, in effect reducing the movement of households from off-grid to on-grid, keeping the number of off-grid households above what they would otherwise have been. More off-grid households increase the pressure on the off-grid water system, resulting in more off-grid households that will need to use the public tap station. This increases the total public water demand and making the actual capacity gap grow even further.

Causal chain: actual capacity gap $\rightarrow$ restrictions on new connections to public grid $\rightarrow$ connections to public grid $\rightarrow$ off-grid households $\rightarrow$ private wells $\rightarrow$ fraction of aquifer exploited $\rightarrow$ average well capacity $\rightarrow$ off-grid water gap $\rightarrow$ water extraction at tap station $\rightarrow$ total on-grid water use $\rightarrow$ actual capacity gap

Behavior: Following the same logic as R1, an increase in actual capacity gap leads to a build up of off-grid households beyond what otherwise would have been. More households lead to more private wells and a greater fraction of aquifer exploited. Over time this leads to a decline in average well capacity because there are fewer and fewer high-capacity well sites left to exploit. This increases the off-grid water gap and, by the same logic as in R1, increases extraction at tap station, rises the total on-grid water use and expands the actual capacity gap even more.

The remaining loops influencing water transports are $R 1, R 2, B 8$ (indirectly) and $B 13 . R 1$ and $R 2$ will both, in theory, contribute to the on-grid water gap by increasing the number of off-grid households that utilizes the public tap station, thereby increasing the total on-grid water use. However, since no data is available on the use of the public tap station, the contribution of these loops to the historic water transports cannot be determined. That said, it is likely that if destination attractiveness is maintained high, e.g. by means of water transports, this will attract more new constructions off-grid and thereby increase the extraction 
at the public tap station (B13). At least during dry years, when the probability of private wells running dry is high, this can contribute to future water transports, in effect shifting the water gap from the private to the public water system. The potential magnitude of this shift is largely governed by loop B8; growth in off-grid households will eventually be limited by the availability of housing sites with sufficient aquifer capacity for building permits to be issued. As described in Table 1, minimum well-capacity requirements for new constructions have been imposed by the municipality, strengthening the effect of loop $B 8$, causing a slowdown in the growth of off-grid households in some parts of the island (Table 3). It thus seems that minimum capacity requirements for off-grid households can both reduce the risk for water scarcity among off-grid consumers, and reduce the need for future water transports. However, since these minimum requirements only apply for new constructions and not for upgrading or expansion of existing houses, off-grid water use per capita and total off-grid water use may continue to increase and contribute to water transports.

To summarize, our findings suggest that the growing need for water transports is a result of the supply-demand cycles created when an increase in water supply contributes to a further increase in demand. In the short run, increasing water transports addresses the symptom of the problem (the on-grid water gap), but the policy fails to address, and may even enforce, the underlying human-water interactions that drive the demand cycles and the lock-in effects they create in the long run.

\subsection{How Can Future Water Scarcity and Increasing Reliance on Water Transports Be Mitigated?}

As our findings suggest, and as supported by previous studies, improvements in regional water self-sufficiency achieved by supply-targeted policies (e.g., inter-basin water transfers or expansion of water reservoirs) will quickly be offset by increased water consumption unless complemented by sufficiently rigorous policies on the demand-side as well (Kallis 2010). Some of the demand targeting policies implemented by RG have contributed to reducing the number of consumers (e.g. by reducing the number of on-grid households and limiting new off-grid constructions to areas with sufficient water supplies) but lasting reductions in water use among already established consumers have not been achieved. We hypothesize this is mainly due to the perception of water sufficiency among consumers that is maintained high due to the reoccurring water transports. Thus, future policies need to be directed towards bringing perceptions of the on-grid water gap closer to the actual water gap, combined with policies that weaken the reinforcing effects increasing supply has on water demand.

Suggestions for suitable policies may be found in previous studies. For instance, Mini et al. (2015) conducted a study on the effectiveness of water conservation measures in California, highlighting that mandatory restrictions, combined with pricing measures, can be effective to reduce household water consumption. On Fårö, consumption tariffs on public water have not been extensively utilized as a policy measure to reduce consumption. Introducing a pricing model where water tariffs are correlated with the level of the actual capacity gap could create incentives to reduce water use. Applying this type of pricing to both on-grid households and to the public tap station (which is currently free of charge) is a possible policy to both bring perceived water sufficiency closer to the real state of water sufficiency, and generate additional income for the municipality to invest in the water supply system. On the other hand, Lu et al. (2019) conducted a study comparing 
the effect of price interventions and behavior interventions on household water consumption in the UK. Results show that behavioral interventions may be more effective than price interventions in regions where the household water bill is relatively small in relation to household income. With the majority of houses on Fårö being part-time holiday houses, typically belonging to high-income consumers (Region Gotland personal communication, 2020-05-11), interventions focusing on behavior rather than price may be more suitable for the region. Also, tourist water use would not be directly addressed by water pricing schemes and therefore campaigns to increase awareness about the fragility of local water resources may be a more effective strategy to reduce tourist water consumption (GabardaMallorquí and Ribas Palom 2016).

Because of the lock-in effects described in section 3.2.1., significant reductions in water supplies is not a realistic policy solution for Fårö. However, gradually increasing local water supply capacity and successively replacing water transports, whilst at the same time controlling total on-grid water use by means of the fiscal and information policy measures described above, could allow for a transition towards water self-sufficiency. Artificial groundwater infiltration, wastewater recycling, seasonal water storage and stormwater utilization are all examples of potential solutions to increase local water supply, see e.g. (Pincetl et al. 2019). Falco and Webb (2015) present the use of "water microgrids" as a promising solution to contribute to both consumer behavioral change and increase the resilience of water supply systems. A distributed system for rainwater collection, storage and distribution could provide significant redundancy as precipitation could be collected and stored during the winter season when many part-time houses are not in use. In the summer, when water demand is high, the collected rainwater can supplement the public grid and greatly reduce the stress on the municipal groundwater aquifers. This would reduce the need for water transports and cut some of the associated logistical costs. The money could instead be directed towards subsidizing household water collection and storage infrastructure. Additionally, turning water consumers to small-scale water producers would make households part of the water supply system. Consumers could monitor the water level of their storage cisterns, constantly maintaining an updated level of perceived water sufficiency, and therefore make more informed decisions regarding their own consumption. Being more responsible for their own water supply, consumers are less likely to make new investments in water-intensive capital, thereby reducing the risk for unintended lock-in effects to occur.

\section{Conclusions}

In this study we have explored how human-water interactions can influence water supply and demand at the local-to-regional scale. We have developed a conceptual model of how water transfers can lead to supply-demand cycles and cause system lock-in effects, pushing previously water-secure regions into a state of escalating water scarcity that is resistant to policy interventions. The case study presented provides a detailed account of some of the systemic feedbacks contributing to this phenomenon and does so in a geographical region largely underrepresented in the socio-hydrological literature. To address the growing reliance on water transports on Fårö, we suggest future policies to focus on a combination of information and economic policy interventions (e.g. demand correlated water tariffs) to incentivize reductions in water use, possibly in combination with a distributed system for rainwater collection, treatment and storage. These policies would contribute to consumer perceptions of the state 
of water resources being more aligned with their actual state, thereby reducing the risk of escalating water use. If these demand-side policies are effective, incomes from the water tariffs could help finance the investments needed for establishing a distributed water supply system, or other measures to increase the local water supply capacity, thereby reducing the need for further water transports.

We want to emphasize that the scope of this study, and the qualitative model developed, do not allow for detailed predictions to be made about what is the "optimal" suit of policies for the studied region. Detailed policy assessments and recommendations would require the development of a quantitative simulation model, which is the next step of this study. That said, we believe that with the anticipated effects of climate change, and the growing demand for water resources, many other regions worldwide are likely to face similar challenges as Fårö in the coming decades. We hope that the findings from this study can support water resources managers in these regions to anticipate the systemic impacts of their strategic choices, and help them account for human-water interactions in the assessment and planning of future water supply systems.

Supplementary Information The online version contains supplementary material available at https://doi.org/ 10.1007/s11269-021-02819-1.

Acknowledgments Thanks to representatives from the Department of Water Management at Region Gotland for their contributions in development and validation of the system map.

Authors' Contributions All authors contributed to the study conception and design. Material preparation, data collection and analysis were performed by A. Nicolaidis Lindqvist and B. Kopainsky, R. Fornell and T. Prade. The first draft of the manuscript was written by A. Nicolaidis Lindqvist and all authors commented on previous versions of the manuscript. All authors read and approved the final manuscript.

Funding Open access funding provided by RISE Research Institutes of Sweden. This research was partially funded by SMHI - Swedish Meteorological and Hydrological Institute, grant "Ansökan for utveckling av verktyg till stöd for samhällets klimatanpassningsarbete, 2019”.

\section{Declarations}

Conflict of Interest The authors declare no conflict of interest.

Open Access This article is licensed under a Creative Commons Attribution 4.0 International License, which permits use, sharing, adaptation, distribution and reproduction in any medium or format, as long as you give appropriate credit to the original author(s) and the source, provide a link to the Creative Commons licence, and indicate if changes were made. The images or other third party material in this article are included in the article's Creative Commons licence, unless indicated otherwise in a credit line to the material. If material is not included in the article's Creative Commons licence and your intended use is not permitted by statutory regulation or exceeds the permitted use, you will need to obtain permission directly from the copyright holder. To view a copy of this licence, visit http://creativecommons.org/licenses/by/4.0/.

\section{References}

Ahopelto L, Veijalainen N, Guillaume JHA, Keskinen M, Marttunen M, Varis O (2019) Can there be water scarcity with abundance of water? Analyzing Water Stress during a Severe Drought in Finland. Sustainability $11: 1548$ 
Andersen DF, Richardson GP (1997) Scripts for group model building. Syst Dyn Rev 13:107-129. https://doi. org/10.1002/(sici)1099-1727(199722)13:2<107::Aid-sdr120>3.0.Co;2-7

Asp M et al. (2015) Framtidsklimat i Gotlands län - enligt RCP-scenarier vol 31. SMHI,

Bahaddin B, Mirchi A, Watkins D, Ahmad S, Rich E, Madani K (2018) System archetypes in water resource management. In: World Environmental and Water Resources Congress 2018. pp 130-140. https://doi.org/10. $1061 / 9780784481400.012$

Bardi U, Lavacchi A (2009) A Simple Interpretation of Hubbert's Model of Resource Exploitation Energies 2: 646-661

Beal C, Makki A, Stewart R (2014) What does reboundingwater use look like? An examination of post-drought and post-flood water end-use demand in Queensland, Australia. Water Sci Technol Water Supply 14:561568. https://doi.org/10.2166/ws.2014.008

Bich-Ngoc N, Teller J (2018) A review of residential water consumption determinants. In pp:685-696. https:// doi.org/10.1007/978-3-319-95174-4_52

Blair P, Buytaert W (2016) Socio-hydrological modelling: a review asking "why, what and how?". Hydrol Earth Syst Sci 20:443-478. https://doi.org/10.5194/hess-20-443-2016

Brunner F (2014) FÖP Fårö - Fördjupad översiktsplan 2025. Region Gotland

Di Baldassarre G, Viglione A, Carr G, Kuil L, Yan K, Brandimarte L, Blöschl G (2015) Debates_perspectives on socio-hydrology: capturing feedbacks between physical and social processes. Water Resour Res 51: 4770-4781. https://doi.org/10.1002/2014WR016416

Di Baldassarre G et al (2018) Water shortages worsened by reservoir effects. Nature Sustainability 1:617-622. https://doi.org/10.1038/s41893-018-0159-0

Di Baldassarre G et al (2019) Sociohydrology: scientific challenges in addressing the sustainable development goals. Water Resour Res 55:6327-6355. https://doi.org/10.1029/2018wr023901

Eklund F (2018) Regional vattenförsörjningsplan för Gotlands län. Visby

Formica S, Uysal M (2006) Destination attractiveness based on supply and demand evaluations: an analytical framework. J Travel Res 44:418-430. https://doi.org/10.1177/0047287506286714

Gabarda-Mallorquí A, Ribas Palom A (2016) Understanding reductions in water consumption in tourist areas: a case study of the Costa Brava, Spain. International Journal of Water Resources Development 32:912-930. https://doi.org/10.1080/07900627.2016.1142861

Gorre-Dale E (1992) The Dublin statement on water and sustainable development. Environ Conserv 19:181-181

Gotland R (2014) Fördjupad översiktsplan för Fårö:2025

Greve P et al (2018) Global assessment of water challenges under uncertainty in water scarcity projections. Nature Sustainability 1:486-494. https://doi.org/10.1038/s41893-018-0134-9

Kallis G (2010) Coevolution in water resource development: the vicious cycle of water supply and demand in Athens. Greece Ecol Econ 69:796-809. https://doi.org/10.1016/j.ecolecon.2008.07.025

Langarudi SP, Maxwell CM, Bai YN, Hanson A, Fernald A (2019) Does socioeconomic feedback matter for water models? Ecol Econ 159:35-45. https://doi.org/10.1016/j.ecolecon.2019.01.009

Markolf SA et al (2018) Interdependent infrastructure as linked social, ecological, and technological systems (SETSs) to address lock-in and enhance resilience. Earth's Future 6:1638-1659. https://doi.org/10.1029/ 2018ef000926

Martinez-Moyano I, Richardson G (2013) Best practices in system dynamics modeling. Syst Dyn Rev 29:29123. https://doi.org/10.1002/sdr.1495

Mirchi A, Madani K, Watkins D, Ahmad S (2012) Synthesis of system dynamics tools for holistic conceptualization of water resources problems. Water Resour Manag 26:2421-2442. https://doi.org/10.1007/s11269012-0024-2

Nations U (2018) SDG 6 synthesis report 2018 on water and sanitation. United Nations. https://doi.org/10.18356/ e8fc060b-en

Pincetl S et al (2019) Adapting urban water systems to manage scarcity in the 21st century: the case of Los Angeles. Environ Manag 63:293-308. https://doi.org/10.1007/s00267-018-1118-2

Rivera P, Ridderstolpe, Djurberg (2011) VA-utredning för Fårö inför fördjupad översiktsplanering

Schwaninger M, Groesser S (2016) System dynamics modeling: validation for quality assurance. In pp 1-20. https://doi.org/10.1007/978-3-642-27737-5_540-3

Seto K, Davis S, Mitchell R, Stokes E, Unruh G, Ürge-Vorsatz D (2016) Carbon lock-in: types, causes, and policy implications. Annu Rev Environ Resour 41:41-452. https://doi.org/10.1146/annurev-environ110615-085934

Sjöstrand Y, Kärrman S, Strömberg V (2014) Metod för val av vattenförsörjning i områden med vattenbrist - en handbok. SP Technical Research Institute of Sweden. Borås, Sweden

Sterman J (2000a) Business dynamics, system thinking and modeling for a complex world https:/www.lstiiepiiep-unescoorg/cgi-bin/wwwi32exe/[in=epidoc1in]/?t2000=013598/(100) 19

Sterman J (2000b) Business dynamics: systems thinking and modeling for a complex world. McGraw-Hill 
Wimmer F et al (2015) Modelling the effects of cross-sectoral water allocation schemes in Europe. Clim Chang 128:229-244. https://doi.org/10.1007/s10584-014-1161-9

Xu L, Gober P, Wheater HS, Kajikawa Y (2018) Reframing socio-hydrological research to include a social science perspective. J Hydrol 563:76-83. https://doi.org/10.1016/j.jhydrol.2018.05.061

Publisher's Note Springer Nature remains neutral with regard to jurisdictional claims in published maps and institutional affiliations.

\section{Affiliations}

\section{Andreas Nicolaidis Lindqvist ${ }^{1,2} \cdot$ Rickard Fornell $^{1} \cdot$ Thomas Prade $^{2} \cdot$ Linda Tufvesson $^{2}$. Sammar Khalil ${ }^{2} \cdot$ Birgit Kopainsky ${ }^{3}$}

1 RISE Research Institutes of Sweden, Ideon Beta5, Scheelevägen 17, 22370 Lund, Sweden

2 Department of Biosystems and Technology, Swedish University of Agricultural Sciences, POO Box 103, SE-230 53 Alnarp, Sweden

3 Department of Geography, System Dynamics Group, University of Bergen, POO Box 7800, 5020 Bergen, Norway 